\title{
Spatial analysis of coral reefs and its degradation patterns in Bunaken National Park
}

\author{
Nafil Rabbani Attamimi ${ }^{1}$ and Ratna Saraswati ${ }^{1, *}$ \\ ${ }^{1}$ Department of Geography, University of Indonesia, Jakarta, Indonesia
}

\begin{abstract}
This article will analyze the spatial pattern as well as the degradation pattern of the coral reefs in the Bunaken National Park. Bunaken National Park is a marine national park located in the Province of North Sulawesi; the park was built as means of conservation as well as providing a region for tourism. The national park contains a different type of marine and land ecosystem, one of the many types of the ecosystem that are in the national park is coral reefs. Coral reefs in Bunaken National Park provides different kinds of function and benefits whether for the marine habitats that live around the ecosystem, as well as for the local people who live in the islands of the national park. Remote sensing could be used as a tool to identify the spatial pattern and the type of ecosystem that habits inside shallow sea water. The main issue with this method is that the research cannot be conduct directly to identify which type of ecosystem specifically (such as coral reefs, seagrass, etc.), as well as its condition. Therefore, data collecting is necessary to observe and identify the ecosystem and its condition specifically. This study uses satellite image from Landsat $8 \mathrm{OLI}$ as the main secondary data to be processed. The satellite image will be processed by using an algorithm of shallow water analysis that was introduced by Lyzenga in 1981. Since data verification and data observation is needed for this study, the research observes the pattern of the different type of ecosystem and its condition that spreads around Bunaken National Park. The verification and observation process was done by GPS, there were 250 different samples from the data that were collected around the Bunaken National Park. The sample that was collected in the study area will be used to classify the satellite image that has been processed by shallow water algorithm, on which could identify: seagrass, bleached coral reefs, deceased coral reefs, and healthy coral reefs around the national park. The results of this study show the spatial pattern of the coral reefs is located usually around the islands in the Bunaken National Park. The results show that the coral reefs are mostly located around the islands in the National Park. The map results show that the healthy coral reefs are usually located in the outermost layer around the shallow water ecosystem. The bleached reefs are usually located in the middle section of the shallow water, between the healthy coral and the islands itself. Most of the reefs that died and bleached are in the southwest of Bunaken Island, and the northwest of Nain Island.
\end{abstract}

\section{Introduction}

\subsection{Study region}

Bunaken National Park is a maritime national park that is located in the northern part of the North Sulawesi Province which is about 15 kilometers north from the City of Manado, the national park is located in the southeastern part of the Celebes Sea. Bunaken National Park has a total area of $890 \mathrm{~km}^{2}$, on which $97 \%$ of it consists of a water body, and the other $3 \%$ are the five islands in the national park, these islands are Bunaken, Mantehage, Manado Tua, Nain, and Siladen. The Bunaken National Park was established in 1991, on which the main purpose of the national park as means of conservation of the marine and the land ecosystem around the area. There are hundreds of different species and habitats that live in the national park. most of them are marine ecosystem such as different type of coral reefs, seagrass, as well as the land habitats that many different types of mangroves species. As for now, the national park is still being conserved and managed by the Indonesian ministry of forestry, as well as for tourism that is visited by Indonesian and foreign tourists [1].

Bunaken National Park is greatly influenced by the monsoon season as well as the El-Nino Cycle since the rainfall and the ocean current in the Celebes Sea is affecting the marine ecosystem in the national park. Other than the meteorological factor, there are around 30 thousand local inhabitants that live in the five islands in the national park. Therefore, their livelihood is dependent on the national park resources as well where their livelihood is impacting the environmental condition in the national park [2].

\subsection{Coral reefs and its condition in Bunaken National Park}

Coral reefs have a significant role in the marine habitat. $33 \%$ of all marine species live or in a way benefit from the coral reefs ecosystem. Other than the importance of coral reefs for the marine habitat, coral reefs also

\footnotetext{
Corresponding author: ratna.saraswati@ui.ac.id
} 
function as a natural barrier against the destructive wave that is impacting towards the coastline [3]. Coral Reefs could also provide economic benefits for people whether it is directly or indirectly. Coral reefs ecosystem is one of the natural marine objects that could be used for tourism. Therefore, coral reefs could get direct economic benefits. It is estimated that coral reefs ecosystem generates around US\$30 billion annually in the tourism sector [4].

Although coral reefs provide benefits for people and play an important role to support marine habitat, the coral reefs are one of an ecosystem that is very sensitive towards environmental change. This is because coral reefs are one of an ecosystem that needs a specific environmental condition for it to live and to develop properly. A slight condition change in the sea could impact the ecosystem severely. A coral reefs ecosystem must have a specific amount of sea surface temperature, salinity, acidity, ocean current, as well as the amount of sunlight received. [3-8]. Therefore, events such as climate change, human activity, extreme meteorological event, etc. could pose a threat towards coral reefs ecosystem and its habitat. Coral reefs could get diseases, bleached, or even die because of these environmental changes.

In terms of morphology, coral reefs ecosystem is usually located within around the island on which the depth of the water is relatively shallow. Coral reefs usually coexist with another shallow water ecosystem such as seagrass. The coral reefs in Bunaken National park are mostly located in the shallow water area within the five islands. But there is an exception on which the coral reefs in Bunaken National park live in the depth of up to 200 meters below the sea level $[9,10]$.

The condition of the coral reefs within the national park is varied, on which there are coral reefs conditions that are healthy, diseased, bleached, and dead [11]. One of the main reason why there are still plenty of healthy coral reefs in this national park is that this national park is still continually being conserved since its main purpose the national park was built to conserve the ecosystem. Nevertheless, there are still coral reefs that are deceased, and bleached. The degradation that happens to the coral reefs could be traced based on a lot of environmental factors. One of the factors that contribute the increasing susceptibility of the condition of the coral reefs is climate change, where the increase of the sea surface temperature, acidity, and the frequency of extreme weather is a strong contributing factor why the coral reefs are degraded in the national park [10]. Other factors that may increase the degraded and damaged coral reefs in the national park is because of human activity. Since the local people are dependent on the livelihood of the marine habitat in the national park it could provide a serious threat to the coral reefs ecosystem without a proper management program [9]. Tourism is also one of the main reason why the coral reefs ecosystem in the national park is being threatened. The national parks are visited by 30,000 tourists annually. Although this benefits greatly for the local economy, it is one of the challenged that have been faced for the conservation program in the national park [1].

\subsection{Remote sensing to identify coral reefs}

Remote sensing and using geographic information system is one of the best tools to identify the spatial distribution, and its condition of a shallow water ecosystem. With remote sensing and geographic information system, it is possible to detect, identify, and see the conditions of coral reefs ecosystem. The satellite image is used as the main data to identify the shallowwater ecosystem which is one of them would be classified as coral reefs.

One of the first research that uses remote sensing as a tool to identify the morphology of shallow water ecosystem was conducted in 1981 by Lyzenga. The research suggests that it is possible to classify different types of morphology in the shallow water by using Landsat satellite image. The main purpose of that research is that the algorithm and function based on the certain value of its reflectance-radiance on a certain band in the imagery. Therefore, an algorithm based on the reflectance-radiance value could be created without the need to know the specific depth of the water itself. The result of shows that within shallow water, the value of reflectance-radiance could be used as an algorithm to detect the morphology of the shallow water if it is relatively homogeneous [12]. The research that was conducted by Lyzenga is one of the first research to identify shallow water morphology. State of the art upon the research of shallow water morphology will most likely refer to Lyzenga.

\section{Methods}

The satellite image is taken by Landsat 8 OLI which was retrieved from the USGS database on which the satellite photo was taken in November 2017.

\subsection{Pre-processing satellite image data}

The first step is to pre-process the Landsat 8 OLI satellite image is to conduct a radiometric correction/atmospheric correction. Radiometric correction is used is used in a satellite image to decrease or remove the effect of the atmosphere radiation that could cause the reflectance value of the image to be distorted. The correction will be based on a value of reflectance and radiance from each band, on which would later be converted to an algorithm.

After conducting a radiometric/atmospheric correction, the next step is to conduct a water column correction. Water column correction is conducted to stabilize the reflectance value of the satellite image. Therefore, water column correction is done to reduce the effect of water attenuation. It will create a formula based on the reflectance value [13].

Pre-processing the satellite image data through water column correction is necessary to conduct before entering the algorithm that has been produced. It is necessary because then classifying the ecosystem and the morphology of the shallow water can be conducted 
thoroughly. Without the water column correction, the process will not be made accurately.

\subsection{Shallow water analysis}

Shallow water analysis is a remote sensing method that uses reflectance radiance value in a satellite image to get an algorithm that will help to detect the shallow water column. In a more generic term, shallow water analysis is a supervised classifying method through an algorithm that can detect the ecosystem beneath the shallow water. This method for this study will be done by using ENVI software. The value of the reflectance values is based on band number 1,2 , and 3 . The calculation of the algorithm formula (1-3) is used three different times in order to retrieve red, blue, and green spectrum. The red spectrum is based on B1 and B2, the green spectrum is based on $\mathrm{B} 1$ and $\mathrm{B} 3$, and the blue spectrum is based on $\mathrm{B} 2$ and $\mathrm{B} 3$.

$$
\begin{aligned}
& Y=\left(\ln 1^{s t} B+(k i / k j) \ln 2^{n d} B\right) \\
& K i / k j=a+\left(a^{2}+1\right)^{1 / 2} \\
& a=\left(\operatorname{Var}\left(1^{s t} B\right)-\operatorname{Var}\left(2^{\text {nd }} B\right) /\left(2 * \operatorname{Covar}\left(1^{s t} B * 2^{\text {nd }} B\right)\right)\right.
\end{aligned}
$$

$\mathrm{Y}$ is the formula for the algorithm to be written in the band math, $1^{\text {st }} \mathrm{B}$, and $2^{\text {nd }} \mathrm{B}$ is the 1 st and the $2^{\text {nd }}$ band formula based on the value of its reflectance radiance, $\mathrm{ki} / \mathrm{kj}$ is a variant and covariant constant which is gotten from $\mathrm{a}$. $\mathrm{a}$ is a value gotten from variant value of the $1^{\text {st }} \mathrm{B}$ and $2^{\text {nd }} \mathrm{B}$ divided by its covariant. $1^{\text {st }} \mathrm{B}$ and $2^{\text {nd }} \mathrm{B}$ means the band number (B1, B2, or B3) depending on the color spectrum.

After the calculation is finished, three different algorithms will be produced on which will display three different color spectrums. The three algorithms are inputted in the band math which will be selected based on the color spectrum in the order of red, green, and blue [14].

\subsection{Sample observation and collection}

The main purpose of sample observation and sample collection in the region of study is to correctly classify the region of interest in the red, green, blue spectrum with the algorithm that has been calculated before. Without collecting sample directly in the region of study, the result will not be as accurate as it should be since there will be no some sort of verification of the region of interest that have been chosen. Therefore, the observing and collecting information will directly verify and validate the region of interest that will be input in the algorithm that has been created.

Sample observation and sample collection are done by plotting different type of classification that needs to be input in the algorithm as many as possible. This research collected 250 sample that consists the classification of the water body such as seagrass, deceased coral reefs, bleached coral reefs, healthy coral reefs, sand/dunes, and deep sea. Other types of classification such as settlements, building, vegetation, etc. are also done. The observation was only done around the island of Bunaken. The sample is collected by using GPS and plot every sample we find.

\subsection{Region of interest and classification}

The plotted sample will then later be converted to a polygon so it can be used as the region of interest by using geographic information system application ArcGIS 10.1. The region of interest that have been converted are inputted to the shallow water algorithm. On which will result in a map that shows the whole study region based on the classification that has been inputted inside the shallow water algorithm.

\section{Results}

\subsection{Sampling results}

Since the purpose of collecting directly from the field is to verify and validate the data on the satellite image, when the research was conducted in the study region researcher managed to find all the types of classification that were assigned before going to the field. The researcher prioritizes plotting the classification in the body of water, such as seagrass, deceased reefs, bleached, reefs, and healthy reefs. Those 4 classifications were all found around the shallow water of Bunaken. the results of the observation were found that seagrass is mostly found the closest coastline alongside the island, where the healthy reefs are found at the edge of the shallow water down to the deep water. Healthy coral reefs were also found within the conservation area. Deceased coral reefs were mostly found between the healthy coral reefs and seagrass; it was also usually found close to settlement and/or tourist area. Lastly, the bleached coral reefs are not so often spotted within Bunaken Island. Figure 1 to 4 that are shown below are pictures of the condition of the coral reefs around Bunaken National Park.

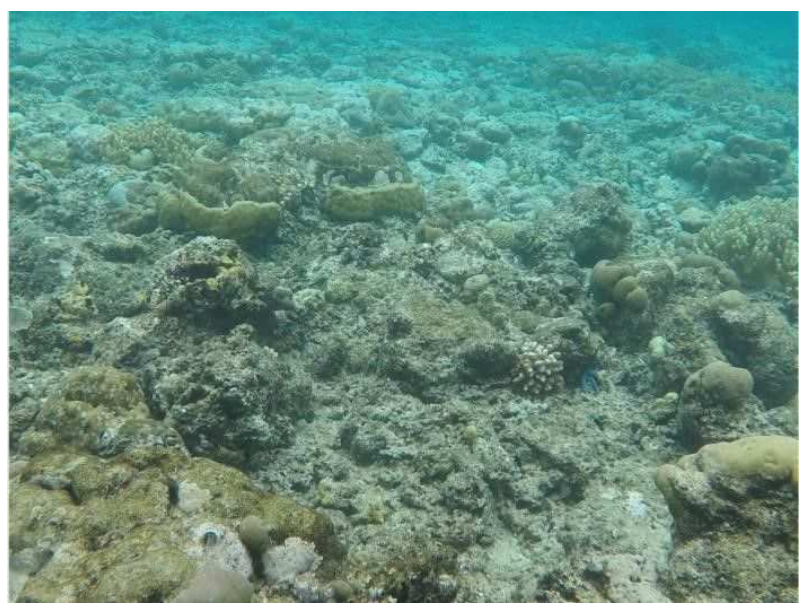

Fig. 1. Deceased coral reefs. 


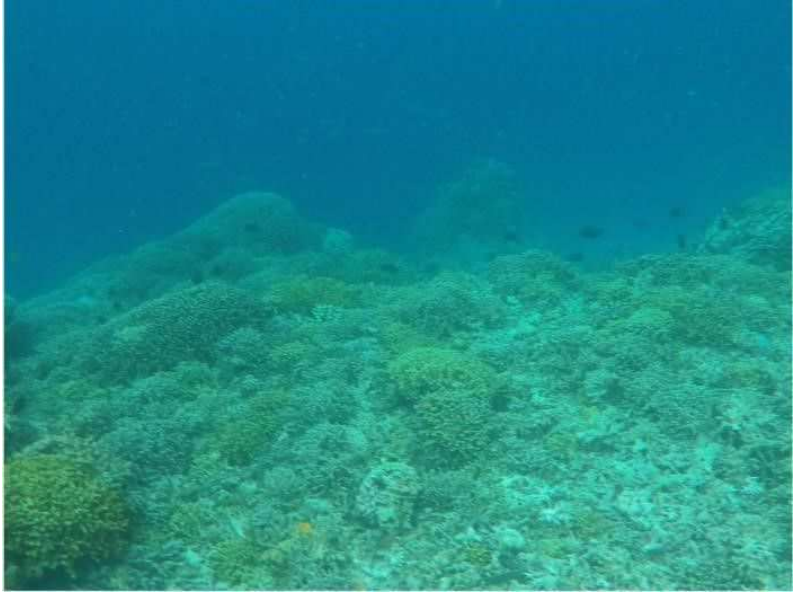

Fig. 2. Relatively green and healthy reefs.

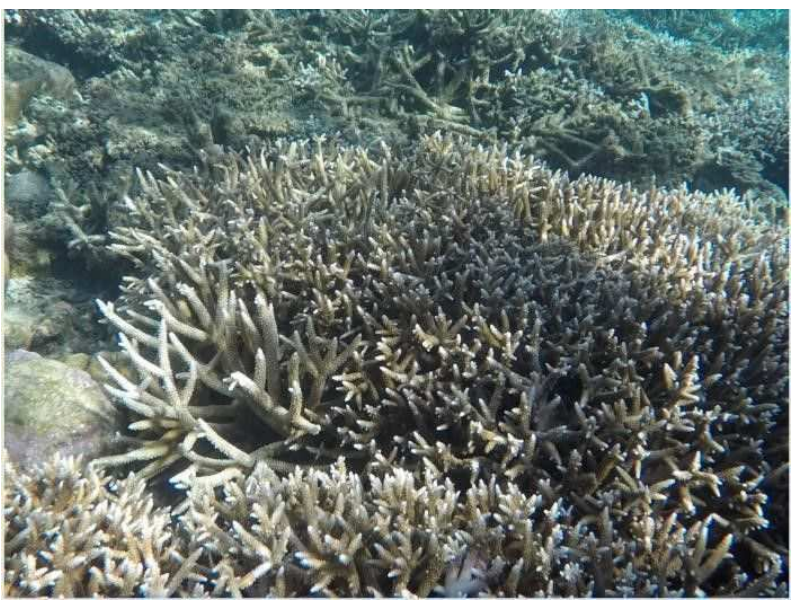

Fig. 3. Bleaching coral reefs.

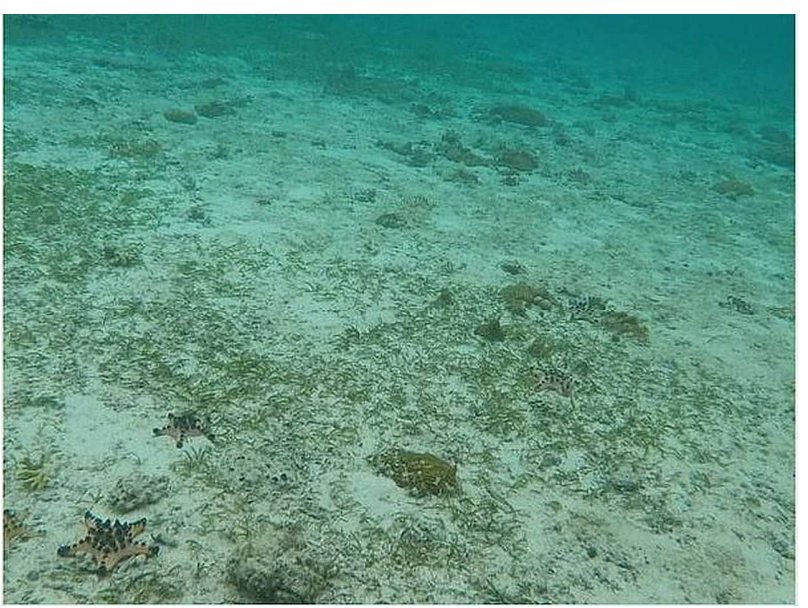

Fig. 4. Seagrass.

\subsection{Shallow water analysis results}

The result of the calculation of algorithm shows that for each color spectrum have the different function of band math formula. The result of the calculation for the formulas is shown in (4-6).

$\operatorname{alog}(B 1-0.131143)-1.020152449 * \operatorname{alog}(B 2-0.125194)(4)$ $\operatorname{alog}(B 1-0.131143)-0.738613163 * \operatorname{alog}(B 3-0.121181)(5)$ $\operatorname{alog}(B 2-0.125194)-0.730138541 * \operatorname{alog}(B 3-0.121181)(6)$
The formula (4) express the red color spectrum for the calculation in band math which consists of band 1 , and band 2. The formula (5) express the green color spectrum for the calculation in band math which consists of band 1, and band 3. The formula (6) express the blue color spectrum for the calculation in band math which consists of band 2 , and band 3 .

The three-color spectrum that has been stacked together could now detect the morphology of the ecosystem I the shallow water by classifying its region of interest. The classification based on the region observation will be input and produce a map that shows the spatial distribution of the coral reefs, as well as the distribution of its degradation within the National Bunaken Park. Figure 5 would show the result of shallow water analysis in a map form.

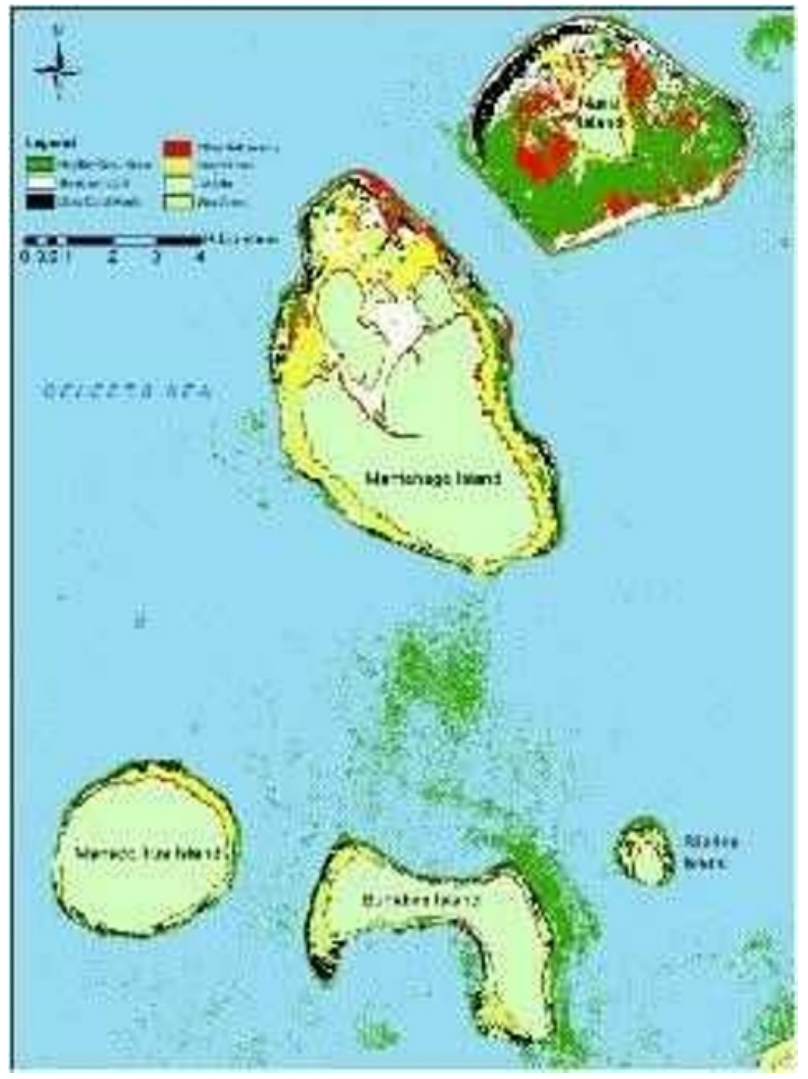

Fig. 5. Spatial distribution and its degradation pattern of coral reefs in Bunaken National Park.

The result of this map shows based on the algorithm from the shallow water analysis, which shows clearly the spatial pattern of its morphology within the Bunaken National Park.

\section{Discussion}

\subsection{Spatial distribution of coral reefs in Bunaken National Park}

From the map that is shown in Figure 5, the pattern of coral reefs could be clearly seen as the color green (healthy reefs), black (deceased reefs), white (bleached reefs), and yellow (seagrass ecosystem). The distribution 
of the seagrass shows a different pattern in each island, as we can see the seagrass could be seen dominantly in Mantehage Island, whereas in other islands the seagrass is distributed between the coastline of the island and coral reefs. The most dominant underwater ecosystem based on the shallow water analysis is the healthy coral reefs. The spatial distribution of the coral reefs in the Bunaken National Park is relatively uneven; it is shown that most of the coral reefs could be found around Bunaken Island and Nain Island, as well as around Mantehage Island. Whereas Manado Tua Island and Sladen Island do not have coral reefs as sprawled as the other islands. The reason could may because that the area of the shallow water around Manado Tua and Siladen Island is not as large as the shallow water around the other islands. Although as we can see that there are coral reefs in the middle of the Celebes Sea, between Bunaken Island and Mantehage Island. Further research should be conducted to identify whether or not there is a shallow water morphology around the Celebes Sea between Bunaken Island and Mantehage Island.

\subsection{Degradation pattern of the coral reefs in the Bunaken National Park}

The healthy coral reefs are spotted almost around all of the islands in the Bunaken National Park. Most especially in the island of Bunaken and the Island of Nain. Healthy reefs are also spotted in Celebes Sea between Bunaken Island and Mantehage Island. One of the key factors that may have contributed the healthy and green condition of the coral reefs in those islands is may perhaps because those are the 2 main areas of conservation. For instance, the northern part of the Bunaken Island there is forest conservation by the inland, and coastal conservation by the coast [15]. Another contributing factor in the northern places of the island that it is forbidden for locals to build a settlement in that region. Therefore, it could be a major factor of why in those regions the coral reefs are healthy.

There are very few coral reefs that the condition is breached it is mostly spotted within the Isles of Mantehage, as well scattered in around Nain Island. The main factor why coral reefs experience bleaching is because the condition of the water tends to warmer than their current ability to sustain.

Although the area of the dead reefs is not as big as the ones that are healthy, the dead reefs that are identified based on this map is alarmingly high. Almost in each of every island in the national park has some sort areas that are identified deceased coral reefs. The area in the north-western part of Nain Island is one of the places where coral reefs have sprawled. The deceased coral reefs also sprawled around the southern part of Bunaken Island. There could be two main factor that may or may not cause the death of these coral reefs. The first factor is because of the human factor, Nain Island, and Bunaken Islands are two of the most populated islands around the National Park. The Nain islanders are permanent settlers where their livelihood mostly depends on fishing and resources from the sea, which could increase the susceptibility of the coral reefs around the northern part of Nain Island. While on Bunaken Island, the southern part of the island is the main area where tourist go. The southern coastal area is the place where tourist goes for a visit and do an activity that involves having direct contact with the fish directly, activity such as snorkeling, and scuba diving. The southern part of the Bunaken Island is also the part where settlement sprawl around the coast, on which the waste that the local produce usually tends to go unmanaged or managed very poorly.

The second factor that may or may not cause the sprawl of the deceased coral reefs is extreme meteorological and climatological event. Since the northern part of the Bunaken National Park is an open ocean directly heading towards the Pacific Ocean, it may have received the direct impact on El- Nino Events. As we can see in Figure 5 that the northern part of Nain Island is sprawled with deceased coral reefs. it is speculated it was because of the recent extreme weather event of El Nino in 2015 where sea surface temperature to increase at an alarming rate that could potentially kill the coral reefs.

Although there are many factors and variable that could potentially degrade the condition of the coral reefs ecosystem in Bunaken National Park, it is complicated to speculate and predict. Further research regarding the cause, the impact, and the implication of the degradation of coral reefs must be conducted in Bunaken National Park for us to know for sure.

\section{Conclusion}

This research will state that it is necessary for the researcher to go to the region of study directly to observe and gather the sample, so the shallow water analysis algorithm could be used sufficiently and reliably. The spatial distribution of the coral reefs is mostly around the island on which are surrounded by shallow water morphology. The degradation pattern of coral reefs mostly consists of deceased coral reefs that are sprawled heavily in the northern Nain Island, as well as southern Bunaken Island. It is speculated that the sprawl of the degradation of the coral reefs may or may not cause by an extreme meteorological factor, and/or human factor.

\section{References}

1. Mehta A, Buku Panduan Lapangan Taman Nasional Bunaken National Park Natural History Book. Balai Taman Nasional Bunaken. (in Indonesian). (1999)

2. World Wildlife Fund, Bunaken National Park Factsheet. WWF-Indonesia. (2009)

3. Crabbe MJC, Climate change, global warming and coral reefs: Modelling the effects of temperature. Computational Biology and Chemistry. (2008)

4. Chen Ping-Yu, Chi-Chung Chen, LanFen Chu, Bruce McCarl. Evaluating the economic damage of climate change on global coral reefs. Global Environmental Change. (2015) 
5. Sparrow Leanne, Paolo Momiglianod, Garry R. Russa, Kirsten Heimanna, Effects of temperature, salinity and composition of the dinoflagellate assemblage on the growth of Gambierdiscus carpenteri isolated from the Great Barrier Reef. Harmful Algae 65 pp. 52-60. (2017)

6. Albright K, R.N. Anthony, Mark Baird, Roger Beeden, Maria Byrne, Catherine Collie, Sophie Dove, Katharina Fabricius, Ove Hoegh-Guldberg, Ryan P. Kelly, Janice Lough, Mathieu Mongin, Philip L. Munday, Rachel J. Pears, Bayden D. Russell, Bronte Tilbrook, Eva Abal, Ocean acidification: Linking science to management solutions using the Great Barrier Reef as a case study. J. Env Management 182, (pp. 641-650). (2016)

7. Hoegh-Guldberg O, P. J. Mumby, A. J. Hooten, R. S. Steneck, P. Greenfield, E. Gomez, C. D. Harvell, P. F. Sale A. J. Edwards, K. Caldeira, N. Knowlton, C. M. Eakin, R. Iglesias-Prieto, N. Muthiga, R. H. Bradbury, A. Dubi,16 M. E. Hatziolos, Coral Reefs Under Rapid Climate Change and Ocean Acidification. Science 318. (2007)

8. Pramanik MK, Climate Change and Sea Surface Temperature: Modelling the Effects on Coral Bleaching. Journal of Earth Science \& Climatic Change. (2014)

9. Indonesian Ministry of Forestery (n.d.). Membangun dan Memperkuat Komitmen Para Pihak dalam Pengelolaan Taman Nasional Bunaken : "Lesson Learn". Nrm- Epiq Programme. (Indonesian).

10. Government of the City of Manado. Kajian Kerentanan Terhadap Perubahan Iklim Kota Manado. (Indonesian).

11. LIPI, Status Terumbu Karang Indonesia 2017. Pusat Penelitian Oseanografi - LIPI. (Indonesian). (2017).

12. Lyzenga. Remote Sensing of Bottom Reflectance and Water Attenuation Parameters in Shallow Water Using Aircraft and Landsat Data. Int. 1. Remote sensing, 2 :1,71-82. (1981)

13. Masita Dwi Mandini Manessa et al. Evaluating The Performance of Lyzenga's Water Column Correction in Case-1 Coral Reef Water Using A Simulated Wolrdview-2 Imagery. Iop Conf. Series: Earth and Environmental Science 47 (2016) 012018 doi:10.1088/1755-1315/47/1/012018.

14. Jaelani, L. M., Laili, N., dan Marini, Pengaruh Algoritma Lyzenga dalam pemetaan Terumbu Karang Menggunakan WorldView-2, Studi Kasus: Perairan PLTU Paiton Probolinggo. Jurnal Penginderaan Jauh, 12(2) 123-131. (2015)

15. Indonesian Ministry of Forestery Pengelolaan Taman Nasional Bunaken Berbasis Resort Bunaken. (Indonesian) (2008) 